\title{
Pengaruh madu terhadap kualitas spermatozoa tikus wistar (Rattus norvegicus) yang diberi paparan asap rokok
}

\author{
${ }^{1}$ Pretty P. Makasenda \\ ${ }^{2}$ Janette M. Rumbajan \\ ${ }^{2}$ Grace L. A. Turalaki
}

\author{
${ }^{1}$ Kandidat Fakultas Kedokteran Universitas Sam Ratulangi Manado \\ ${ }^{2}$ Bagian Biologi Fakultas Kedokteran Universitas Sam Ratulangi Manado \\ Email: pretty.makasenda@gmail.com
}

\begin{abstract}
Cigarettes are composed of hazardous chemicals such as nicotine, tar and carbon monoxide (CO) to name a few. In just a single puff of a cigarette, there are 1014 free radical molecules also known as Reactive Oxygen Species (ROS) that can cause sperm damage. Various natural ingredients native to Indonesia were found to contain various antioxidants, one of them is honey. The effects of honey as antioxidant may protect body cells in neutralizing free radicals caused by smoking and reducing the damage to spermatozoa cell that is caused by ROS and thereby avoiding the declining quality of spermatozoa. This study aimed to determine the effect of honey on the quality of spermatozoa of Wistar rats (Rattus norvegicus) that had been exposed to cigarette smoke. Subjects of this study were nine male Wistar rats (Rattus norvegicus) randomly divided into three groups weighing 150-200 g with the age range of 12-14 weeks. Each group of mice was given exposure to the smoke of 2 cigarettes a day in which the treatment group $\left(\mathrm{P}_{1}\right)$ is also given $0.5 \mathrm{ml}$ of honey per day, and the treatment group $\left(\mathrm{P}_{2}\right)$ honey $1 \mathrm{ml} /$ day. The results showed that honey treatment can improve concentration, motility, and morphology of spermatozoa Wistar rats (Rattus norvegicus) by exposure to cigarrets smoke. Occurred a significant difference of concentration, motility, and morphology of spermatozoa group given only the exposure to cigarette smoke and the group given exposure to cigarette smoke and honey. This results showed that $1 \mathrm{ml}$ of honey per day could improve the quality of spermatozoa.
\end{abstract}

Keywords: honey, cigarrets smoke, spermatozoa

\begin{abstract}
Abstrak: Rokok mengandung bahan kimia yang berbahaya, yaitu nikotin, tar dan gas karbon monoksida (CO). Dalam satu kali hisapan rokok terdapat 1014 molekul radikal bebas atau Reactive Oxygen Species (ROS) yang dapat merusak spermatozoa. Berbagai bahan alam asli Indonesia banyak mengandung antioksidan, salah satunya pada madu. Efek madu sebagai antioksidan dapat melindungi sel-sel tubuh termasuk menetralisir radikal bebas yang disebabkan oleh rokok dan mengurangi kerusakan sel spermatozoa yang disebabkan oleh ROS sehingga menghindari menurunnya kualitas spermatozoa. Penelitian ini bertujuan untuk mengetahui pengaruh madu terhadap kualitas spermatozoa tikus wistar (Rattus norvegicus) yang diberi paparan asap rokok. Subjek penelitian ini menggunakan 9 ekor tikus wistar (Rattus norvegicus) jantan yang dibagi menjadi tiga kelompok secara acak dengan berat badan 150-200 gram dan berumur 12-14 minggu. Masing-masing kelompok tikus diberi paparan asap rokok 2 batang / hari dimana kelompok perlakuan $\left(\mathrm{P}_{1}\right)$ juga diberi madu $0.5 \mathrm{ml}$ / hari, dan kelompok perlakuan $\left(\mathrm{P}_{2}\right)$ diberi madu $1 \mathrm{ml} /$ hari. Hasil penelitian memperlihatkan bahwa pemberian madu dapat meningkatkan konsentrasi, motilitas, dan morfologi spermatozoa tikus wistar (Rattus norvegicus) yang diberi paparan asap rokok. Terjadi perbedaan yang bermakna dari konsentrasi, motilitas, dan morfologi spermatozoa kelompok yang hanya diberi paparan asap rokok dan kelompok yang diberi paparan asap rokok dan
\end{abstract}


madu. Hasil tersebut menunjukan bahwa madu $1 \mathrm{ml} /$ hari dapat meningkatkan kualitas spermatozoa.

Kata kunci: madu, asap rokok, spermatozoa

Rokok mengandung bahan kimia yang berbahaya, yaitu nikotin, tar dan gas karbon monoksida (CO). ${ }^{1}$ Kebiasaan merokok dapat menimbulkan berbagai penyakit yang dapat membahayakan kesehatan manusia. ${ }^{2}$ Bahaya rokok sudah diketahui semua orang, tetapi perilaku merokok tidak pernah berkurang bahkan sudah menjadi masalah kesehatan dunia hingga saat ini. ${ }^{3,4}$ Rokok merupakan salah satu penyumbang terbesar penyebab kematian yang sulit dicegah dalam masyarakat.

Asap rokok mengandung ribuan komponen kimia yang menghasilkan radikal bebas. ${ }^{5}$ Diperkirakan dalam satu kali hisapan rokok terdapat 1014 molekul radikal bebas atau Reactive Oxygen Species (ROS) yang dapat merusak spermatozoa. ROS yang meningkat melebihi sistem pertahanan antioksidan tubuh dapat menurunkan kualitas spermatozoa. ${ }^{6}$

Tubuh manusia memiliki sistem pertahanan antioksidan (antioksidan endogen) untuk melawan radikal bebas dan molekul berbahaya lainnya yang ada di dalam tubuh. Antioksidan endogen, yaitu enzim-enzim yang bersifat antioksidan, seperti: Superoksida dismutase (SOD), katalase (Cat), dan glutathione peroksidase $(\mathrm{Gpx}){ }^{7}$ Apabila radikal bebas dan molekul berbahaya lainnya tersebut terdapat dalam jumlah yang berlebihan, maka tubuh memerlukan antioksidan dari luar tubuh atau makanan (antioksidan eksogen) untuk melawannya. ${ }^{8}$ Berbagai bahan alam asli Indonesia banyak mengandung antioksidan, salah satunya pada madu.

Komponen utama dari madu yang bersifat sebagai antioksidan adalah vitamin E, vitamin $\mathrm{C}$ dan betakaroten. ${ }^{8,9}$ Efek madu sebagai antioksidan dapat melindungi selsel tubuh termasuk menetralisir radikal bebas yang disebabkan oleh rokok dan mengurangi kerusakan sel spermatozoa yang disebabkan oleh ROS sehingga menghindari menurunnya kualitas spermatozoa. $^{10,11}$

Penelitian ini bertujuan untuk mengetahui pengaruh madu terhadap kualitas spermatozoa tikus wistar (Rattus norvegicus) yang diberi paparan asap rokok.

\section{METODE PENELITIAN}

Penelitian ini merupakan penelitian eksperimental laboratorium dengan metode analitik menggunakan pendekatan post test only control group design. Penelitian ini dilakukan di Laboratorium Biologi Fakultas Kedokteran Universitas Sam Ratulangi dengan rentan waktu dari bulan September sampai November 2016 selama 50 hari. Sampel penelitian ini menggunakan 9 ekor tikus wistar (Rattus norvegicus) jantan yang dibagi menjadi tiga kelompok secara acak dengan berat badan 150-200 gram, berumur 12-14 minggu, diberikan makan dan minum secara ad libitum. Masing-masing kelompok tikus mendapat perlakuan berbeda, yaitu; kelompok kontrol $\left(\mathrm{P}_{0}\right)$ diberi paparan asap rokok 2 batang / hari, kelompok perlakuan $\left(\mathrm{P}_{1}\right)$ diberi paparan asap rokok 2 batang / hari dan diberi madu $0.5 \mathrm{ml} /$ hari, dan kelompok perlakuan $\left(\mathrm{P}_{2}\right)$ diberi paparan asap rokok 2 batang / hari dan diberi madu $1 \mathrm{ml} /$ hari.

\section{HASIL PENELITIAN}

\section{Pengaruh madu terhadap konsentrasi spermatozoa tikus wistar (Rattus norvegicus) yang diberi paparan asap rokok.}

Setelah dilakukan paparan asap rokok dan pemberian madu selama 50 hari, dilakukan penelitian terhadap konsentrasi spermatozoa tikus wistar (Rattus norvegicus) pada masing-masing perlakuan, dilihat pada tabel 1 rerata konsentrasi spermatozoa kelompok $\mathrm{P}_{1}$ dan $\mathrm{P}_{2}$ mengalami peningkatan dibandingkan dengan rerata konsentrasi spermatozoa 
kelompok $\mathrm{P}_{0}$. Kelompok $\mathrm{P}_{0}$ memiliki rerata konsentrasi spermatozoa sebanyak $40.7 \mathrm{x}$ $10^{6}$ spermatozoa / $\mathrm{ml}$ sementara kelompok perlakuan $\mathrm{P}_{1}$ dan $\mathrm{P}_{2}$ memiliki rerata konsentrasi spermatozoa berturut-turut sebanyak $62.1 \times 10^{6}$ spermatozoa / $\mathrm{ml}$ dan $90.9 \times 10^{6}$ spermatozoa / ml.

Tabel 1. Hasil perhitungan rerata konsentrasi spermatozoa tikus wistar (Rattus norvegicus) setelah pemaparan asap rokok dan pemberian madu.

\begin{tabular}{cc}
\hline Kelompok sampel & $\begin{array}{r}\text { Rerata Konsentrasi Spermatozoa } \\
\mathbf{x ~ 1 0} \mathbf{6}^{\mathbf{s p e r m a t o z o a}} / \mathbf{~ m l}\end{array}$ \\
\hline Kontrol (P0) & 40.7 \\
Perlakuan (P1) & 62.1 \\
Perlakuan (P2) & 90.9 \\
\hline
\end{tabular}

Pengaruh madu terhadap motilitas spermatozoa tikus wistar (Rattus norvegicus) yang diberi paparan asap rokok.

Hasil pengamatan terhadap motilitas spermatozoa tikus wistar (Rattus norvegicus) dikategorikan dalam empat kategori, yaitu kategori A spermatozoa yang bergerak cepat dan lurus ke depan, kategori B spermatozoa yang bergerak lambat kedepan dan berbelok-belok, kategori $\mathrm{C}$ bergerak di tempat, dan kategori D tidak bergerak. Berdasarkan kategori diatas didapatkan persentase motilitas spermatozoa normal yaitu motilitas kategori A dan B, dan motilitas abnormal yaitu motilitas ketegori C dan D. Setelah dilakukan perlakuan, penilaian motilitas dan pengelompokan data, didapati hasil rerata persentase motilitas spermatozoa tikus wistar (Rattus norvegicus) dapat dilihat pada tabel 2.

Tabel 2. Hasil perhitungan rerata persentase motilitas spermatozoa tikus wistar (Rattus norvegicus) setelah pemaparan asap rokok dan pemberian madu.

\begin{tabular}{ccc}
\hline \multirow{2}{*}{ Kelompok sampel } & \multicolumn{2}{c}{ Rerata Motilitas Spermatozoa } \\
\cline { 2 - 3 } & Normal (\%) & Abnormal (\%) \\
\hline Kontrol (P0) & 17 & 83 \\
Perlakuan 1 (P1) & 29 & 71 \\
Perlakuan 2 (P2) & 60 & 40 \\
\hline
\end{tabular}

Berdasarkan Tabel di atas dapat dilihat penurunan rerata motilitas spermatozoa normal dan peningkatan rerata spermatozoa abnormal. Kelompok $\mathrm{P}_{0}$ memiliki rerata motilitas spermatozoa normal sebanyak $17 \%$ dan abnormal sebanyak $83 \%$. Kelompok $\mathrm{P}_{1}$ memiliki rerata motilitas spermatozoa normal sebanyak $29 \%$ dan abnormal sebanyak $71 \%$. Kelompok $\mathrm{P}_{2}$ memiliki rerata motilitas spermatozoa mormal sebanyak $60 \%$ dan abnormal sebanyak $40 \%$.
Pengaruh madu terhadap morfologi spermatozoa tikus wistar (Rattus norvegicus) yang diberi paparan asap rokok.

Penilaian terhadap morfologi spermatozoa tikus wistar (Rattus norvegicus) terbagi menjadi dua yaitu morfologi normal dan abnormal. Penilaian morfologi abnormal dilihat dari abnormalitas kepala, abnormalitas leher dan abnormalitas ekor. Hasil yang didapatkan dari rerata morfologi spermatozoa pada penelitian ini sebagai berikut: 
Tabel 3. Hasil perhitungan rerata persentase morfologi spermatozoa tikus wistar (Rattus norvegicus) setelah pemaparan asap rokok dan pemberian madu.

\begin{tabular}{ccc}
\hline \multirow{2}{*}{ Kelompok Sampel } & \multicolumn{2}{c}{ Rerata Morfologi Spermatozoa } \\
\cline { 2 - 3 } & Normal (\%) & Abnormal (\%) \\
\hline Kontrol (P0) & 37 & 63 \\
Perlakuan 1 (P1) & 65 & 35 \\
Perlakuan 2 (P2) & 75 & 25 \\
\hline
\end{tabular}

Berdasarkan Tabel di atas dapat dilihat terjadi penurunan rerata morfologi spermatozoa normal pada kelompok $\mathrm{P}_{0}$ dan berbanding terbalik dengan kelompok lainnya. Kelompok $\mathrm{P}_{0}$ memiliki rerata morfologi spermatozoa normal sebanyak $37 \%$ dan, kelompok $\mathrm{P}_{1}$ memiliki rerata morfologi spermatozoa normal sebanyak $65 \%$, dan kelompok $\mathrm{P}_{2}$ memiliki rerata morfologi spermatozoa normal tertinggi sebanyak $75 \%$.

Pada tabel rerata morfologi abnormal, kelompok $\mathrm{P}_{0}$ memiliki persentase tertinggi sebanyak $63 \%$ dan kelompok $\mathrm{P}_{2}$ memiliki persentase terendah sebanyak $25 \%$. Kelompok $\mathrm{P}_{1}$ memiliki persentase morfologi abnormal sebanyak $35 \%$.

Uji komparabilitas antar kelompok penelitian membandingkan kualitas spermatozoa yaitu konsentrasi spermatozoa, motilitas spermatozoa, dan morfologi spermatozoa antar kelompok $\mathrm{P}_{0}$ terhadap kelompok $\mathrm{P}_{1}$, kelompok $\mathrm{P}_{0}$ terhadap kelompok $\mathrm{P}_{2}$, dan kelompok $\mathrm{P}_{1}$ terhadap kelompok $\mathrm{P}_{2}$. Pada penelitian ini uji komparabilitas yang digunakan adalah independent sampel t-test karena berdasarkan uji normalitas dan homogenitas, data terdistribusi normal dan homogen.

Uji komparabilitas kelompok kontrol $\left(\mathrm{P}_{0}\right)$ dan perlakuan $1\left(\mathrm{P}_{1}\right)$ memperlihatkan hasil analisis perbandingan antar kelompok $\mathrm{P}_{0}$ yang diberi paparan asap rokok sebanyak 2 batang per hari dan kelompok $\mathrm{P}_{1}$ yang diberi paparan asap rokok sebanyak 2 batang per hari dan madu 0.5 $\mathrm{ml}$ per hari (Tabel 4).

Tabel 4. Perbandingan kualitas spermatozoa kelompok kontrol $\left(\mathrm{P}_{0}\right)$ dan kelompok perlakuan $1\left(\mathrm{P}_{1}\right)$

\begin{tabular}{|c|c|c|c|}
\hline Kualitas Spermatozoa & $\begin{array}{c}\text { Kelompok } \\
\text { Kontrol }\left(\mathbf{P}_{\mathbf{0}}\right)\end{array}$ & $\begin{array}{c}\text { Kelompok } \\
\text { Perlakuan } 1 \\
\left(\mathbf{P}_{1}\right)\end{array}$ & Nilai $p$ \\
\hline Konsentrasi & 40.7 & 62.1 & 0.093 \\
\hline Motilitas Normal & 17 & 29 & 0.012 \\
\hline Morfologi Normal & 37 & 65 & 0.004 \\
\hline
\end{tabular}

Hasil uji komparabilitas kualitas spermatozoa antara kelompok $\mathrm{P}_{0}$ dan kualitas spermatozoa kelompok $\mathrm{P}_{1}$, mendapatkan nilai $\mathrm{p}<0.05$ pada perbandingan motilitas normal (0.012) dan morfologi normal $(0.004)$ yang berarti ada perbedaan bermakna pada rerata motilitas dan morfologi antar kelompok $\mathrm{P}_{0}$ dan kelompok $\mathrm{P}_{1}$. Hasil analisis perbandingan rerata konsentrasi spermatozoa kelompok
$\mathrm{P}_{0}$ dan kelompok $\mathrm{P}_{1}$ tidak menunjukkan perbedaan bermakna (nilai $\mathrm{p}=0.093$ ).

Uji komparabilitas kelompok kontrol $\left(\mathrm{P}_{0}\right)$ dan perlakuan $2\left(\mathrm{P}_{2}\right)$ memperlihatkan hasil analisis perbandingan antar kelompok $\mathrm{P}_{0}$ yang diberi paparan asap rokok sebanyak 2 batang per hari dan kelompok $\mathrm{P}_{2}$ yang diberi paparan asap rokok sebanyak 2 batang per hari dan madu $1 \mathrm{ml}$ per hari (Tabel 5). 
Tabel 8. Perbandingan kualitas spermatozoa kelompok kontrol $\left(\mathrm{P}_{0}\right)$ dan kelompok perlakuan $2\left(\mathrm{P}_{2}\right)$

\begin{tabular}{cccc}
\hline $\begin{array}{c}\text { Kualitas } \\
\text { Spermatozoa }\end{array}$ & $\begin{array}{c}\text { Kelompok } \\
\text { Kontrol }\left(\mathbf{P}_{\mathbf{0}}\right)\end{array}$ & $\begin{array}{c}\text { Kelompok } \\
\text { Perlakuan 2 }\left(\mathbf{P}_{\mathbf{2}}\right)\end{array}$ & Nilai p \\
\hline Konsentrasi & 40.7 & 90.9 & 0.007 \\
Motilitas Normal & 17 & 60 & 0.000 \\
Morfologi Normal & 37 & 75 & 0.001 \\
\hline
\end{tabular}

Berdasarkan tabel diatas, dilihat hasil uji komprabilitas kualitas spermatozoa antara kelompok $\mathrm{P}_{0}$ dan kualitas spermatozoa kelompok $\mathrm{P}_{2}$, didapatkan nilai $\mathrm{p}<0.05$ pada perbandingan konsentrasi (0.007), motilitas (0.000), dan morfologi (0.001) yang berarti ada perbedaan bermakna pada rerata konsentrasi, motilitas dan morfologi antar kelompok $\mathrm{P}_{0}$ dan kelompok $\mathrm{P}_{2}$.
Uji komparabilitas kelompok perlakuan $1\left(\mathrm{P}_{1}\right)$ dan perlakuan $2\left(\mathrm{P}_{2}\right)$ memperlihatkan hasil analisis perbandingan antar kelompok $\mathrm{P}_{1}$ yang diberi paparan asap rokok sebanyak 2 batang per hari dan madu $0.5 \mathrm{ml}$ per hari dan kelompok $\mathrm{P}_{2}$ yang diberi paparan asap rokok sebanyak 2 batang per hari dan madu $1 \mathrm{ml}$ per hari disajikan dalam tabel 6.

Tabel 6. Perbandingan kualitas spermatozoa kelompok perlakuan $1\left(\mathrm{P}_{1)}\right.$ dan kelompok perlakuan $2\left(\mathrm{P}_{2}\right)$

\begin{tabular}{lccc}
\hline Kualitas Spermatozoa & $\begin{array}{c}\text { Kelompok } \\
\text { Perlakuan 1 }\end{array}$ & $\begin{array}{c}\text { Kelompok Perlakuan } \\
\mathbf{2}\left(\mathbf{P}_{\mathbf{1}}\right)\end{array}$ & Nilai p \\
Konsentrasi & 40.7 & 90.9 & \\
Motilitas Normal & 17 & 60 & 0.587 \\
Morfologi Normal & 37 & 75 & 0.000 \\
Morfologi Abnormal & 63 & 35 & 0.031 \\
\hline
\end{tabular}

Berdasarkan Tabel 6, dilihat hasil uji komprabilitas kualitas spermatozoa antara kelompok $\mathrm{P}_{1}$ dan kualitas spermatozoa kelompok $\mathrm{P}_{2}$, didapatkan nilai $\mathrm{p}<0.05$ pada perbandingan motilitas normal (0.000), morfologi normal (0.031), dan morfologi abnormal (0.037) yang berarti ada perbedaan bermakna pada rerata motilitas dan morfologi antar kelompok $\mathrm{P}_{1}$ dan kelompok $\mathrm{P}_{2}$. Hasil analisis perbandingan rerata konsentrasi spermatozoa kelompok $\mathrm{P}_{1}$ dan kelompok $\mathrm{P}_{2}$ tidak menunjukkan perbedaan yang bermakna dengan nilai $\mathrm{p}=0.587$.

\section{BAHASAN}

Pengaruh madu terhadap konsentrasi spermatozoa tikus wistar (Rattus norvegicus) yang diberi paparan asap rokok.

Berdasarkan data penelitian pada tabel 1, dapat dilihat bahwa rerata konsentrasi spermatozoa tikus wistar (Rattus norvegicus) setelah diberi paparan asap rokok dan diberi madu mengalami peningkatan dibanding dengan kelompok kontrol yang hanya diberi paparan asap rokok. Kelompok $\mathrm{P}_{0}$ yang diberi paparan asap rokok menunjukkan rerata konsentrasi rendah yaitu $40.7 \times 10^{6}$ spermatozoa / ml. Kelompok perlakuan $\left(\mathrm{P}_{1}\right)$ yang diberi paparan asap rokok dan diberi madu $0.5 \mathrm{ml}$ dan kelompok perlakuan $\left(\mathrm{P}_{2}\right)$ yang diberi paparan asap rokok dan diberi madu $1 \mathrm{ml}$ menunjukkan rerata konsentrasi yang lebih tinggi yaitu $\mathrm{P}_{1}$ sebesar $62.1 \mathrm{x} \quad 10^{6}$ spermatozoa / $\mathrm{ml}$ dan $\mathrm{P}_{2}$ sebesar $90.9 \times 10^{6}$ spermatozoa / ml. Dari hasil analisis 
tersebut, pemberian madu dapat meningkatkan konsentrasi spermatozoa tikus wistar yang diberi paparan asap rokok.

\section{Pengaruh madu terhadap motilitas spermatozoa tikus wistar (Rattus norvegicus) yang diberi paparan asap rokok.}

Berdasarkan data penelitian pada tabel 2, dapat dilihat bahwa rerata motilitas normal spermatozoa tikus wistar (Rattus norvegicus) setelah diberi paparan asap rokok dan diberi madu mengalami peningkatan dibanding dengan kelompok kontrol yang hanya diberi paparan asap rokok dan motilitas abnormal spermatozoa tikus wistar (Rattus norvegicus) kelompok perlakuan mengalami penurunan dibanding kelompok kontrol. Kelompok $\mathrm{P}_{0}$ yang diberi paparan asap rokok menunjukkan rerata motilitas normal spermatozoa yang rendah yaitu $17 \%$ dan rerata motilitas abnormal spermatozoa yang tinggi yaitu 83 $\%$. Sedangkan kelompok $\mathrm{P}_{1}$ dan $\mathrm{P}_{2}$ yang diberi paparan asap rokok dan diberi madu menunjukkan rerata motilitas normal spermatozoa yang lebih tinggi yaitu $\mathrm{P}_{1}$ sebesar $29 \%$ dan $\mathrm{P}_{2}$ sebesar $60 \%$. Rerata motilitas spermatozoa yang abnormal lebih rendah yaitu $\mathrm{P}_{1}$ sebesar $71 \%$ dan $\mathrm{P}_{2}$ sebesar $40 \%$. Dari hasil analisis tersebut, pemberian madu dapat meningkatkan motilitas normal spermatozoa dan menurunkan motilitas abnormal spermatozoa tikus wistar (Rattus norvegicus) yang dipapari asap rokok.

\section{Pengaruh madu terhadap morfologi spermatozoa tikus wistar (Rattus norvegicus) yang diberi paparan asap rokok.}

Berdasarkan data penelitian pada tabel 3, dapat dilihat bahwa rerata morfologi normal spermatozoa tikus wistar (Rattus norvegicus) setelah diberi paparan asap rokok dan diberi madu mengalami peningkatan dibanding dengan kelompok kontrol yang hanya diberi paparan asap rokok dan motilitas abnormal spermatozoa tikus wistar (Rattus norvegicus) kelompok perlakuan mengalami penurunan dibanding kelompok kontrol. Kelompok $\mathrm{P}_{0}$ yang diberi paparan asap rokok menunjukkan rerata morfologi normal spermatozoa yang menurun yaitu $37 \%$ dan rerata morfologi abnormal spermatozoa yang tinggi yaitu 63 $\%$. Kelompok $\mathrm{P}_{1}$ dan $\mathrm{P}_{2}$ yang diberi paparan asap rokok dan diberi madu menunjukkan rerata morfologi normal spermatozoa yang lebih tinggi yaitu $\mathrm{P}_{1}$ sebesar $65 \%$ dan $\mathrm{P}_{2}$ sebesar $75 \%$, sedangkan rerata morfologi abnormal spermatozoa yang lebih rendah yaitu $\mathrm{P}_{1}$ sebesar $35 \%$ dan $\mathrm{P}_{2}$ sebesar $25 \%$. Dari hasil analisis tersebut, pemberian madu dapat meningkatkan morfologi normal spermatozoa dan menurunkan morfologi abnormal spermatozoa tikus wistar (Rattus norvegicus) yang dipapari asap rokok.

\section{Uji komparabilitas antar kelompok penelitian}

a. Uji komparabilitas kelompok kontrol $\left(\mathrm{P}_{0}\right)$ dan perlakuan $1\left(\mathrm{P}_{1}\right)$

Berdasarkan hasil analisis perbandingan kualitas spermatozoa antar kelompok $\mathrm{P}_{0}$ yang diberi paparan asap rokok sebanyak 2 batang per hari dengan kelompok $\mathrm{P}_{1}$ yang diberi paparan asap rokok sebanyak 2 batang per hari dan madu $0.5 \mathrm{ml}$ per hari pada tabel 7, tidak ditemukan perbedaan bermakna pada konsentrasi spermatozoa. Tetapi pada motilitas dan morfologi antara kelompok $\mathrm{P}_{0}$ dengan kelompok $\mathrm{P}_{1}$ terdapat perbedaan yang bermakna.

b. Uji komparabilitas kelompok kontrol $\left(\mathrm{P}_{0}\right)$ dan perlakuan $2\left(\mathrm{P}_{2}\right)$

Berdasarkan hasil analisis perbandingan kualitas spermatozoa antar kelompok $\mathrm{P}_{0}$ yang diberi paparan asap rokok sebanyak 2 batang per hari dengan kelompok $\mathrm{P}_{2}$ yang diberi paparan asap rokok sebanyak 2 batang per hari dan madu $1 \mathrm{ml}$ per hari pada tabel 8 , ditemukan perbedaan bermakna pada konsentrasi, motilitas dan morfologi antara kelompok $\mathrm{P}_{0}$ dengan kelompok $\mathrm{P}_{2}$.

c. Uji komparabilitas kelompok perlakuan $1\left(\mathrm{P}_{1}\right)$ dan perlakuan $2\left(\mathrm{P}_{2}\right)$ Berdasarkan hasil analisis 
perbandingan kualitas spermatozoa antar kelompok $\mathrm{P}_{1}$ yang diberi paparan asap rokok sebanyak 2 batang per hari dan madu $0.5 \mathrm{ml}$ per hari dengan kelompok $\mathrm{P}_{2}$ yang diberi paparan asap rokok sebanyak 2 batang per hari dan madu 1 $\mathrm{ml}$ per hari pada tabel 7 , tidak ditemukan perbedaan bermakna pada konsentrasi spermatozoa. Tetapi pada motilitas dan morfologi antara kelompok $\mathrm{P}_{1}$ dengan kelompok $\mathrm{P}_{2}$ terdapat perbedaan yang bermakna.

Hasil penelitian kualitas spermatozoa yang dilakukan pada tikus wistar (Rattus norvrgicus) setelah diberi madu menunjukkan terjadinya peningkatan kualitas spermatozoa yaitu motilitas dan morfologi spermatozoa. Peningkatan kualitas spermatozoa yang disebabkan oleh pemberian madu karena sifat antioksidan madu yang dapat menetralisir radikal bebas yang disebabkan oleh asap rokok. ${ }^{10,11} \mathrm{Hal}$ ini sesuai dengan penelitian sebelumnya yang dilakukan oleh Legowo $G$ tentang manfaat madu sebagai antioksidan yang berperan melawan radikal bebas rokok untuk menjaga kualitas spermatozoa. ${ }^{6}$

Asap rokok mengandung komponen gas yang menghasilkan radikal bebas. Kelebihan radikal bebas atau oksigen reaktif (ROS) berpotensi merusak kualitas spermatozoa. ROS yang meningkat melebihi sistem pertahanan antioksidan tubuh akan menimbulkan stres oksidatif. ${ }^{12}$ Stres oksidatif menyebabkan kerusakan sel, jaringan, atau organ. Efek negatif yang dihasilkan oleh stres oksidatif terhadap spermatozoa menimbulkan peningkatan hilangnya motilitas, peningkatan kerusakan membran, penurunan morfologi. ${ }^{13}$

Komponen utama dari madu yang bersifat sebagai antioksidan adalah vitamin E, vitamin $\mathrm{C}$ dan betakaroten. ${ }^{8,9}$ Efek madu sebagai antioksidan dapat melindungi selsel tubuh termasuk menetralisir radikal bebas yang disebabkan oleh rokok dan mengurangi kerusakan sel spermatozoa yang disebabkan oleh ROS sehingga menghindari menurunnya kualitas spermatozoa. $^{10,11}$

\section{SIMPULAN}

1. Pemberian madu dapat meningkatkan kualitas spermatozoa tikus wistar (Rattus norvrgicus) yang diberi paparan asap rokok.

2. Pemberian madu dapat meningkatkan konsentrasi spermatozoa tikus wistar (Rattus norvegicus) yang diberi paparan asap rokok.

3. Pemberian madu dapat meningkatkan motilitas spermatozoa tikus wistar (Rattus norvegicus) yang diberi paparan asap rokok.

4. Pemberian madu dapat meningkatkan morfologi spermatozoa tikus wistar (Rattus norvegicus) yang diberi paparan asap rokok.

5. Terjadi perbedaan yang bermakna dari konsentrasi, motilitas, dan morfologi spermatozoa kelompok yang hanya diberi paparan asap rokok dan kelompok yang diberi paparan asap rokok dan madu.

\section{SARAN}

1. Perlu dilakukan penelitian lebih lanjut mengenai pengaruh madu terhadap kualitas spermatozoa tikus wistar (Rattus norvegicus) terhadap kualitas spermatozoa dalam dosis yang berbeda.

2. Perlu dilakukan penelitian lebih lanjut mengenai zat-zat dalam madu yang paling berperan dalam meningkatkan kualitas spermatozoa.

\section{DAFTAR PUSTAKA}

1. Tirtosastro S, Murdiyati AS. Kandungan Kimia Tembakau dan Rokok. Buletin Tanaman Tembakau, Serat dan Minyak Industri. April 2010;2:33-47

2. Jamal S. 2006. Pria Desa Berpendidikan Rendah, Perokok Terbanyak. Peneliti di badan Pengembangan Kesehatan Jakarta. Medika Jurnal Kedokteran Indonesia No.03 tahun ke XXXII, Maret 2006

3. Lingkungan Keluarga Harmonis Sejahtera Menuju Keluarga Kecil Bahagia Sejahtera. 2007 [diakses pada tanggal 11 September 2016]. Available from: http://www.bkkbn.go.id/arsip/Docum 
ents/Lingkungan\%20Keluarga/Bahay a\%20rokok.doc.

4. Nurrahmah. Pengaruh Rokok Terhadap Kesehatan dan Pembentukan Karakter Manusia. Seminar Nasional Pendidikan Karakter; 3 Mei 2014; Gedung SCC Palopo. [diakses pada tanggal 11 September 2016]. Available from:

http://journal.uncp.ac.id/index.php/proceding/ar ticle/view/226/215

5. Fitria, Triandhini RR, Mangimbulude JC, Karwur FF. Merokok dan Oksidasi DNA. Sains Medika vol.5. 2013 Desember. 2; h.113-20.

6. Legowo G. Manfaat Madu Sebagai Antioksidan dalam Melawan Radikal Bebas Rokok untuk Menjaga Kualitas Sperma. Majority. 2015;5(8):141-6

7. Werdhasari A. Peran Antioksidan Bagi Kesehatan. Jurnal Biotek Medisiana Indonesia. 2014;3(2):59-68

8. Budiman J, Istiadi $\mathbf{H}$, Amarwati $\mathbf{S}$. Pengaruh Madu Terhadap Gambaran Mikroskopis Testis Pada Tikus Wistar yang Diinduksi Monosodium Glutamat. MMM. Oktober
2015;4:1040-8.

9. Igbokwe VU, Samuel O. Pure Honey Potent Fertility Booster: Activities of Honey on Sperm. IOSR J Dent Med Sci. 2013; 9(6): 43-7

10.Kobori Y,Ota S, Sato R, Yagi H,Soh S,Arai G,et al. Antioxidant cosupplementation therapy with vitamin C,vitamin E, and coenzyme Q10 in patients with oligoasthenozoospermia. Archivio Italiano di Urologia e Andrologia. 2014;86:1-4.

11.Bansal AK, Bilaspuri GS. Antioxidant effect of vitamin $E$ on cattle spermatozoa. Animal Science Papers and Reports. 2009;27:5-14.

12.Davar R, Sekhavat L, Naserzadeh N. Semen Parameters of Non-infertile Smoker and Non-smoker Men. Journal of Medicine and Life. 2012;5:465-8

13.Eisenberg, Li S, Behr B, et al. Semen Quality, Infertility and Mortality in The USA Human Reproduction. 2014; 29(7): $\quad$ p1567-74 